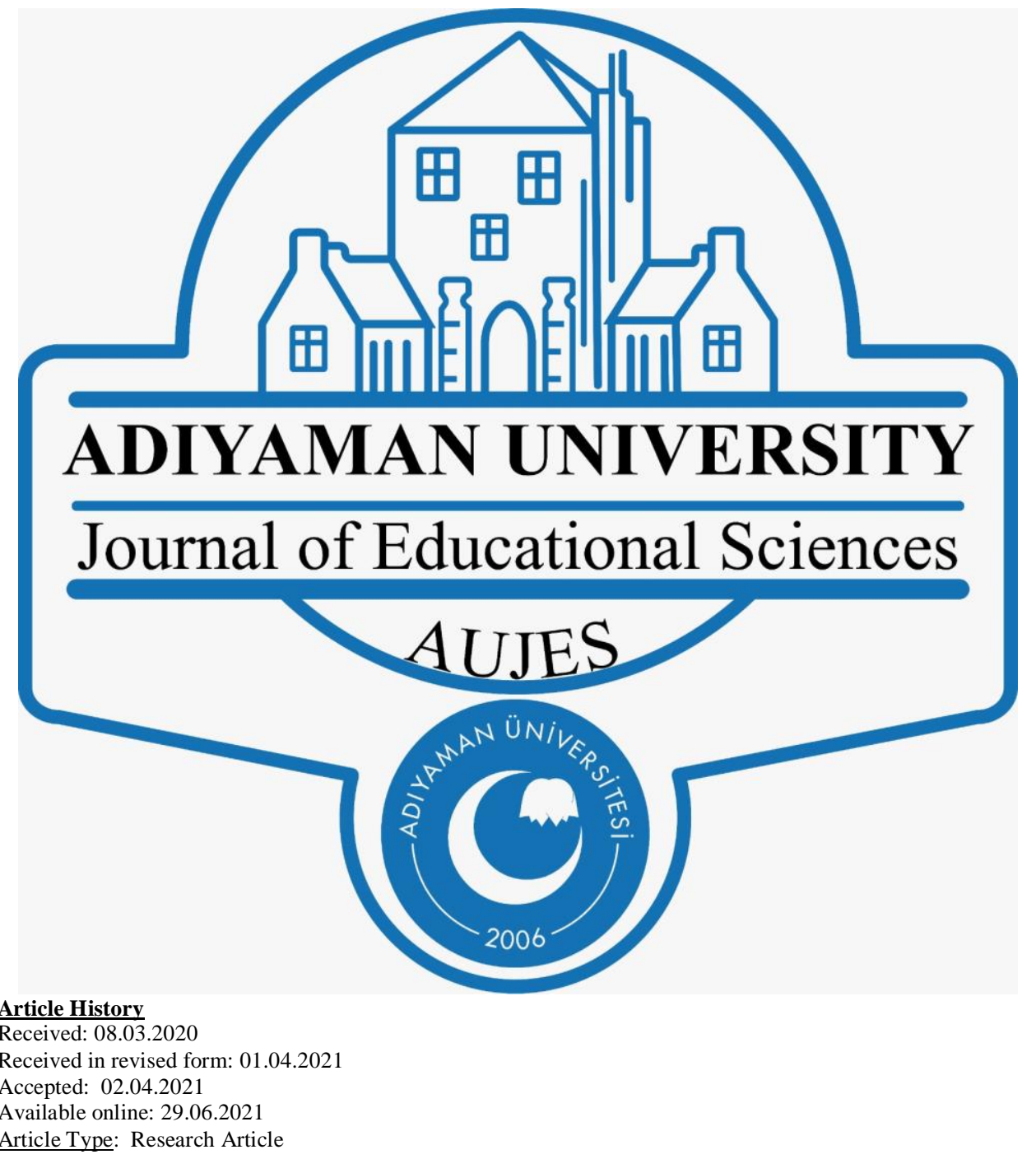

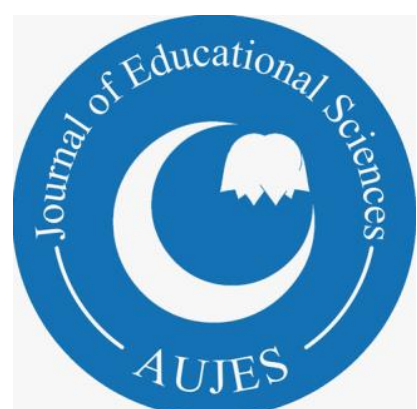

ADIYAMAN UNIVERSITY

Journal of Educational Sciences (AUJES) https://dergipark.org.tr/tr/pub/adyuebd

Learning English as a Second Language through Translanguaging in Early Years ${ }^{*}$

\author{
İskender Gelir ${ }^{1}$ \\ ${ }^{1}$ Early Childhood Education, Siirt University/ Early \\ Childhood Education, Sultan Qaboos University, Oman (iD)
}

To cite this article:

Gelir, İ. (2021). Learning English as a second language through translanguaging in early years. Adiyaman Univesity Journal of Educational Sciences, 11(1), 1-8.

* A version of this work was presented at VII. International Eurasian Educational Research Congress. 



\title{
Learning English as a Second Language Through Translanguaging in Early Years
}

\author{
Iskender Gelir ${ }^{*}$, \\ ${ }^{1}$ Early Childhood Education, Siirt University, Turkey/Early Childhood Education, Sultan Qaboos University, \\ Oman
}

\begin{abstract}
This study examines preschool children's learning English as a second language in early years education. It is qualitative and uses ethnography as the data collection and analysis method. It was conducted between October 2019 and January 2020 in a private nursery in a city in Turkey. The participant children are 5 and 6 years old. In this study, different bilingual models are discussed, and the construct of translanguaging is used to examine children's second language and literacy learning, and their interactions with the teacher and peers in the classroom. The findings show that preschool children learn language and literacy through a flexible language teaching method. The study demonstrates that their expressive skills, vocabulary learning, and math develop in classroom activities. The findings also indicate that the model enables the participant children to improve their first language (Turkish) skills.
\end{abstract}

Key words: English, second language learning, models, preschool, translanguaging

\section{Introduction}

In early childhood education, English is widely taught and spoken as a second/foreign language in both private and state funded schools in many countries (Lugossy, 2018; Prošic- Santovac and Radovič, 2018). This provides English to have prestigious in many societies. Thus, parents and teachers have appetite for their children and students to learn English from early years. In spite of this, Koru and Åkesson found that the importance of English is not understood considerably and that there is a gap between students' competence in English countries such as Turkey and Brazil. In Turkey, parents increasingly want their children to learn English in early years education. However, in Turkey learning English as a second language is mainly taught in private nurseries (Sarica, 2019). In state-funded nurseries, English is taught in kids club that are arranged after daily activities have finished in Turkish (Official Gazette, 2014, article no:83).). But kids club are not arranged in every nursery as they are paid for and based on parents' choices (Gelir, 2020). In kids club, it is considered that there is language separation as the English language teacher teaches English (mainly grammar and speaking skills) after the preschool teacher has finished daily activities (Gelir, 2020). The language separation is mainly associated with the immersion method.

According to Çetintaş and Yazıcı (2016), immersion method is mainly used as a language teaching model in early years education in Turkey. The immersion method is criticised for separating languages (Schwartz and Asli, 2014). In recent years, however, translanguaging model is applied for teaching children two or more languages flexibly. Translanguaging is also used as a theoretical construct.

This study will indicate how translanguaging can be used as a teaching model in early years education. However, it seems that there is limited research on translanguaging both as a teaching model and construct in the relevant literature in Turkey. For example, this model is used in a few nurseries, and it has been used to examine English language teachers' perceptions of teaching English as second language in different levels of education such as primary and secondary (Yuvayapan, 2019) and Syrian refugee children in Turkey (Baytas and Seyma, 2019). Therefore, the current study aims to contribute to this gap by using the construct of translanguaging to investitage preschool children's learning English as a second language in a private nursery. This study addresses the following research question:

- How do preschool children learn English language and literacy?

\section{Theoretical Framework}

There are two main approaches to second language learning: bottom up and top down. Bottom- up approaches suggested that learning a second language (including reading) starts from small unit of meaning

\footnotetext{
* Corresponding Author: İskender Gelir, campus97@,hotmail.com
} 
such as individual sound and phoneme to general knowledge of structure and language (syntactic knowledge). This means that sounds and words play important roles in understanding of language and structure as 'decoding sounds and pronouncing words is seen as a means to gain understanding' (Gregory, 2008, p.109). In contrast, top- down approaches claim that learning a second language begins with understanding of general knowledge to particular. These approaches argue that experience is crucial to a second language learning as a learner builds meaning through experience. In other words, the recognition of printed and written symbols is seen as a stimulus for remembering meaning (Gregory, 2008).

There are also theories of second language learning. In this paper, cognitive, sociocultural and sociolinguistic theories will be discussed with a focus on sociolinguistic theories. Cognitive approaches argued that there are systems that function without awareness and that each individual can access to. Cognitive approaches argued that a second language learning is integrated into the cognitive mechanism that is already established through the first language. These approaches claimed that the same learning mechanism is used to understand structures and patterns form a second language. Cognitive approaches also viewed memory, sentence processing, information processing and attention as important in second language learning (Mitchell, Myles and Marsden, 2013). On the other hand, sociocultural theories considered that a second language is learned in interactions with more knowledgeable adults or peers in social contexts. Sociocultural theories are based on Vygotsky's works $(1978,1986)$. Vygotsky argued that the child first learns in interactions with people around her/him, and then s/he internalises his learning. That is, this theory viewed a second language learning as a social practice. Although sociocultural theory claimed that the child neurobiology is crucial to human mental functioning, her or his cognitive system develop in interaction with people and the social context (Lantolf and Thorne, 2006; Lantolf, Thorne \& Poehner, 2015). For sociocultural theories, language is an important cultural tool that mediates an individual connection to the social context and people around.

Similarly, sociolinguistic theory claimed that a second language is learned in a social context that affects children language use and development (Tarone, 2007). This means that this theory investigated how a social context and learner' participation affect the rate and direction of second language relearning and outcome (Mitchell, Myles and Marsden, 2013). Tarone (2007) argued that a second language is not learned in vacuum, rather, it is learned from and with people. The relationships between the learner and social context have effects on cognitive development. Scholars advocating sociolinguistic theories also emphasised the relationship between culture and language use. Researchers such as Bayyurt (2013) suggested that cultural elements such as accent can be included in teaching a second/ foreign language. According to Bayyurt, this provides positive attitudes towards a second language learning. I situate my study within sociolinguistic, which emphasised the role of social and cultural contexts in learning a second language.

\section{Second Language Learning Models and Translanguaging}

Researchers suggested different models of teaching children English as a second language in early years. They based their models either on language separation (e.g., by time, activity and teacher) or language integration. In either case, the goal was to improve children's second language learning in early years. ProšićSantovac and Radović (2018) examined the language separation model (one teacher-one language) applied in a Serbian- English bilingual kindergarten. In this model, instructions were given in both Serbian and English. The authors found that the applied model had advantages and disadvantages. Their results showed that language separation during instruction had positive affect on children's receptive language skills. But expressive skills (e.g., communication) were not improved as much as those of receptive. Likewise, Lugossy (20018) explored immersion the use of the immersion model in teaching English as a second language in two private preschool settings in Hungarian. The author observed that the English language teachers were in the classrooms during different times of the day. For example, one of the teachers was available during mornings, and the other one was in the classroom all day. The author also observed children's language use that English was mainly used during mealtime (e.g., breakfast and lunch) (Lugossy, 20018).

In the immersion bilingual education model, children learn the second language that can be socially dominant and prestigious. This bilingual education model was first applied in Canada (Baker, 2007). In addition, Bayyurt (2012) suggested a content- based instruction for learning English as a second language. In this model, concepts first are introduced to children in their first language (e.g., Turkish), and then a week later these concepts are introduced in English. In other words, learning concepts in English follow learning them in Turkish. It could be argued that learning English is a repetition of what they have learned in Turkish. In the content- based model, learning English is not considered a situated activity (e.g., second language learning taking place in classroom interactions and is used for different purposes). Instead, English is learned through repetition and translation of content and concepts from Turkish.

Schwartz and Asli (2014) criticised these models for keeping language discrete and separate. In other words, these models do not allow children to use languages flexibly. The authors suggested that flexible 
language use supported children bilingualism, not 'double monolingualism' in classrooms (Schwartz and Asli, 2014, p.22). This referred to the concept of translanguaging that considered that children can use their full linguistic resources to maximise their understanding and developing their second language learning. In recent years, scholarship focused on this construct to understand and analyse children's language use in classrooms' interactions. Translanguaging allows children to use their multiple discursive practices (García, 2009) and to move between languages (García and Wei, 2014). Researchers suggested that teachers can develop children's second language learning (e.g., English) in early childhood education (Mifsud and Vella, 2018; Schwartz and Asli, 2014; Ting and Jintang, 2020). A recent study by Ting and Jintang (2020), which examined preschool children's English language learning in Malaysia, indicated that teachers used translanguaging to develop children' competence in English by providing cues and supporting children's expressive skills. It is worth highlighting that there are mainly two types of the use of translanguaging: pedagogy and practice. Translanguaging as pedagogy is mainly supported and practiced by schools (Creese and Blackledge, 2015). But translanguging as practice is used by individual teachers (Mary and Young, 2017. In other words, translanguaging as practice is not officially supported by the curriculum. The private nursery in which this research was conducted used translanguaging as pedagogy.

\section{Method}

This study was conducted between October 2019 and January 2020. Its method was ethnography, which had a qualitative approach to data collection and analysis. Ethnography requires a researcher to observe children in their social settings such as school on a long- term basis (Gregory, 2005). This method allowed the researcher to observe how young children learn a second language (English) in classroom activities. Ethnography was also chosen to document children's learning as the time progresses. In other words, the goal was to document how children's English language learning changed during the process. The researcher wanted to observe children's learning in classrooms activities and interactions with each other and the teacher. In addition, this paper drew on Copland and Creese's (2015) concept of linguistic ethnography, which linked learning to social contexts and aimed to find how children use language (Copland and Creese, 2015).

In this research, participant observation, and audio and video recordings were used as data collection methods. Audio and video recorders were also used to record children's interactions with the English language teacher in classroom activities such as speaking and math. I visited the classroom one day peer week during the fieldwork, and (each visit lasted around one hour). The researcher observed children's participation in English activities and how the children respond to the teacher during interactions. The researcher put the phone on the top of a cupboard to record interactions while taking fieldnotes.

\section{Setting and Participants}

In Turkey, there are state funded and private nurseries. The state funded nurseries follow a unified curriculum, meaning that every state-funded nursery applies the same programme although teachers can adapt it to their local context in terms of activities. English as a second language can be taught only in a few statefunded nurseries. However, private nurseries can teach young children English as a second language as these preschools have their own programme. The data in this study was drawn from a study investigating children learning English as a second language early years in a city in Turkey. The school had more than 80 children at the time of the study. The participants children were 5 and 6 years old, and from socio- economically advantaged families as the nursery was private and their family paid fees. The majority of the parents were mainly from different cities and appointed by the government in different in state sectors.

In the school, there were four classrooms, of which had two teachers: the English language teacher and preschool teacher. The English teacher (Ayşe) was graduated from English Language and Literature department. She had the postgraduate certificate in education (PGCE). Based on the teacher's self-repots, she was not trained to teach young children English. But she had in-service training to young children English. Each teacher was responsible for each language in the classroom. The English teacher organised activities for English language. The teachers defined their language model as flexible and activity- based. It was observed that their model can be defined as co-teaching (Schwartz and Gorbatt, 2018). Because both teachers were in the classroom except during music activities, which were given by a different teacher, and they helped each other to develop the children's learning. This paper focused on interactions taking place during English language activities.

\section{Data Analysis}

In this study, the collected data were given codes to make interactions understandable (Gibbs, 2007), and then the codes were put into categories. The purpose of giving a code was to identify what took place in an interaction. For example, "learning the nose" was considered a code to suggest that the children learn the lexical item nose in English. This code was subsumed under the category expressive skills. This study used linguistic ethnography that suggested an interpretive approach to and a bottom- up approach to data analysis (Copland and 
Creese, 2015). This means that a researcher works from data to theory. As the data were collected and analysed, the researcher searched for and examined the literature on learning English as a second language. In other words, the data and the researcher's participant observations in the classroom guided the researcher to choose the relevant literature.

\section{Results and Discussion}

This section will analyse the main categories that were emerged from the data. Three main categories were identified: developing expressive skills, vocabulary learning and math learning. The teacher sometimes nominates children to take on the role of a teacher to practice their learning. In such activities, the children sit on chairs and the child teacher sits on the front of the other children. In the activity below, the teacher nominates Emre to be a child teacher to ask his friends for the names of the body parts showed on the flashcards. The interaction shows how the teacher translanguages to develop the child's expressive skills.

Turkish is italic, and English is regular throughout.

\section{Developing expressive skills}

Excerpt 1: Learning the nose

1 Teacher: Emre, you are going to ask your friends questions.

2 Emre: What is this? [holds flashcard showing a nose]

3 Children: This is a nose.

4 Teacher: Emre, bir daha sor (ask one more time) [the other children do not say it loudly]

5 Emre: What is this?

6 Children: This is a nose [loudly] (Video recording, 25/11/2019)

In this excerpt, the teacher guides Emre to practise expressive skills in English (Turn 1). Emre, asks his friends for answering what is shown on the flash card (Turn 2). The other children respond to him by saying that is a nose (Turn 3), but it seems that the teacher is not satisfied with their response as she asks them for saying loudly quietly (Turn 4). The teacher encourages Emre to ask for his friend again by saying "bir daha sor" in Turkish (Turn 4). In other words, the teacher uses Turkish to guide Emre for repeating what he has said. He asks his friends, and they respond to him with a higher tone (Turn 6). This excerpt shows that the teacher uses the languages flexibly in order to develop children's expressive skills. The children are emerging bilingual. Because they are in the early stage of learning English as a second language. This interaction shows that the children's expressive language skills develop as they take on the role of the teacher (Gregory, 2001).

In the next interaction, the teacher asks the children where they come from. The purpose of examining this activity is to show how the teacher develops the children's English language learning. In this interaction, the teacher nominates each child to say their hometown.

Fieldnotes 2: Defining their hometown

1 Teacher: Where are you from, Can?

2 Can: I am from Ankara.

3 Teacher: Where are you from, Ayla?

4 Ayla:... (silent)

5 Teacher: Söyle, nereli olduğunu. (say, where you are from)

6 Ayla: I am from Kastamonu (Fieldnotes, 01/11/2019).

In this excerpt, the teacher relates the activity to the children's daily life via using both languages. The teacher nominates Can and asks him to say his hometown (Turn 1). Can responds to her with a grammatically sentence (Turn 2). The teacher asks another child to say where she comes from (Turn 3). Ayla does not respond to the teacher (Turn 4). It seems that Ayla does not understand the question in English. Because Ayla responds the question in Turkish (Turn 6). when the teacher asks her the question in Turkish (Turn 5).

The teacher supports the child's language learning by using Turkish. This is an example of using the languages flexibly in order to develop children's English learning. In this interaction the children contextualise their second language learning by saying the names of their hometown in English. In contrast to the strict language separation model, the participant teacher follows and applies a language learning model that enables her to help the children where necessary. Through translanguaging in this activity, the teacher scaffolds the child to practise her new language (Wood et al., 1976).

In the activity below, the teacher introduces the children to occupations by using flashcards. The following excerpt indicates how the teacher supports children's vocabulary learning in a second language. 


\section{Vocabulary learning}

Fieldnotes 3: Learning the names of the occupations

1 Teacher: This is a mechanic (holds the flashcard of a mechanic)

2 Children: Mechanic (only a few children repeat)

3 Teacher: Mechanic, tamirci (mechanic) [the teacher says it in both languages]

4 Children: Mechanic [all children] (Fieldnotes, 08/11/2019).

In this interaction, the teacher translanguages to teach the children the mechanic occupation. First, the teacher introduces the children to the occupation by showing the flashcard (Turn 1). The teacher wants the children to repeat after her. Only a few children repeat what the teacher has said (Turn 2). This time, she says the occupation in English and then in Turkish in order to enable the children to produce the vocabulary (Turn 3). All the children repeat after her only in English (Turn 4). In this activity, the teacher develops children's vocabulary learning in English by providing the meaning of mechanic in Turkish. In so doing, the teacher helps the children to understand the meaning of the mechanic occupation. This activity shows that the teacher encourages the children to learn new vocabulary by using both languages at the same time. It seems that the teacher's use of Turkish stimulates children's speaking skills (e.g., vocabulary learning) in English.

\section{Math learning}

The figure below was taken from a math activity in which the children developed their math skills. In such activities, as the figure shows, the children are given the instruction in both languages. Figure 1: Learning the geometric shapes.

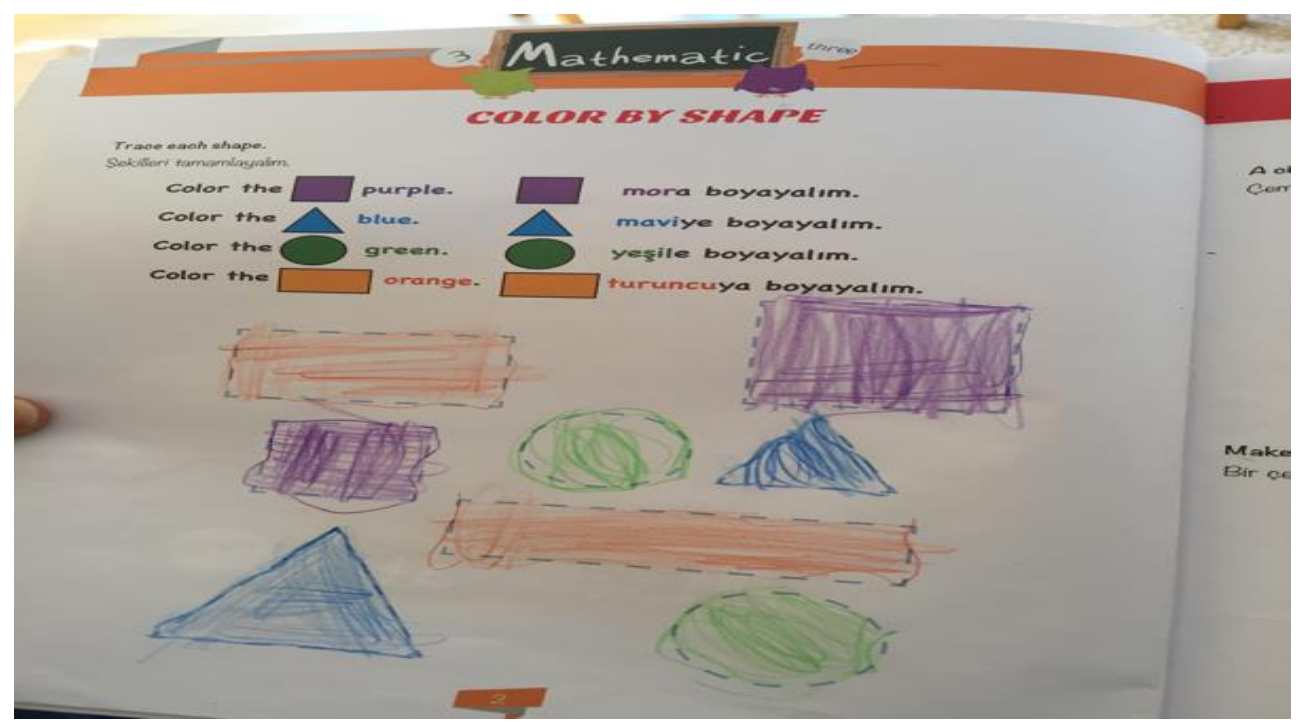

Figure 1. shows the instructions for the names of geometric shapes in Turkish and English.

This is an example that shows that the children's Turkish and English language develop through a flexible model that allows both languages to be used in the activity. In this activity, the children's language skills such as math and art developed by tracing dots and, painting and learning the names of geometrical shapes. In this activity, the children learn the names of geometric shapes and colours in English and Turkish as well. This activity also indicates that young children can learn two languages simultaneously (Kenner, 2004) without separating the languages. 


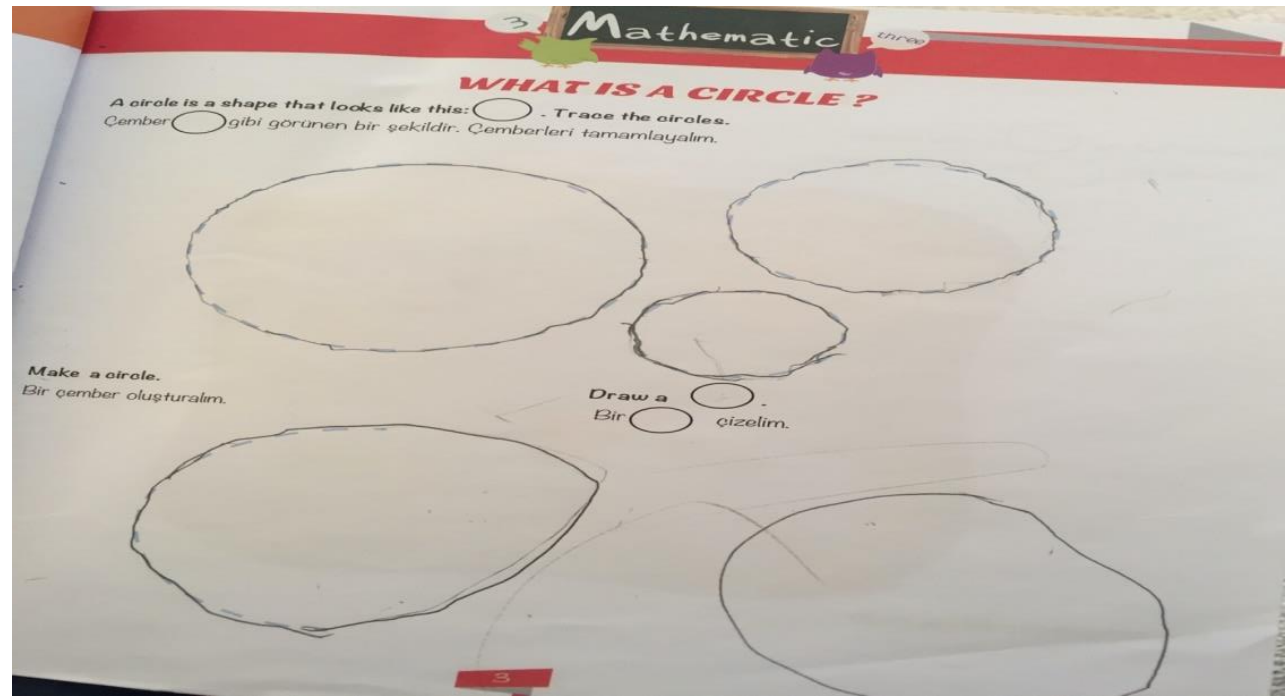

Figure 2. indicates children' learning circles.

For this activity sheet, the instructions are given in both English and Turkish. This activity develops children's math skills in both languages. The children learn the concept of the circle in math. They also learn the lexical items "draw" and "make" in English. They differentiate the lexical items from each other and practice the items by tracing the dots and making a new circle.

\section{Conclusion}

This paper has examined children's English language and literacy learning in a preschool setting. It highlighted the role of flexible language use in learning a second language. The findings of this study were vocabulary learning, expressive skills and math skills. This paper showed that the children's second language learning developed through participation in English language activities such as literacy and math. The excerpts showed that vocabulary learning plays an important role in learning a second language. The more the child knows vocabulary, the better s/he can develop her/his expressive skills. The children's expressive skills developed by taking on the role of the teacher. For example, in the excerpt 1 the teacher nominated the children to instruct their friends by taking on her role (Gregory, 2001). This study supported Protassova's (2018) study, which investigated Russian immigrant children learning Finnish in Finland. Protassova used the concept of translanguaging as a theoretical construct to examine children's second language learning in a setting where flexible language teaching model was used. The study demonstrated that the teachers organised activities that improved children's second language learning. She found that bilingualism had a positive effect on children's academic achievement. Their expressive language skills developed through translanguaging in the classrooms' activities. That is, the findings contrasted with Lugossy's (2018) study, which found that language separation by teacher was effective only in children receptive skills.

Strict dual language programmes can constrain language use in classrooms. But translanguaging can enable children to use their linguistic resources (Gort and Sembiante, 2015). In this study, the English language teacher allowed the children to use both languages in order to develop their learning and to familiarise them with literacy learning (e.g., vocabulary). This accorded with Gort and Sembiante' (2015) study, which examined children's language learning in a dual language programme. Gort and Sembiante (2015) found that flexible language use played an important role in children's participation in classroom's activities. The findings supported Schwartz and Palviainen's (2016) study that showed that two languages can be used or learned in combination. As Figure 1 indicated, the children were given instruction in both Turkish and English in a math activity. This enabled them to learn two languages simultaneously (Kenner, 2008). In so doing, the children made sense of their new language through scaffolding from the teacher (Wood et al., 1976).

The children developed their speaking (expressive) and writing skills (see Figure 1) through translanguaging. This study considered that when teachers teach a second language, they can have a holistic approach to teach it. This meant that they do not necessarily focus on vocabulary learning and expressive skills. They can also teach science and math in a second language. This study was at odds with Çetintaş and Yazici's (2016) study that examined the preschool teachers and English language teachers' views of teaching English in early years education. Defining immersion method one teacher-one language, Çetintaş and Yazici (2016) argued that this had advantages for teaching children English. But their study missed an important point that children's learning is more likely to be limited in the immersion method as children need to want to use one language at one time and the other language at another time. In other words, there can be a strict language use in the 
classroom. However, Garcia (2009) pointed out that children can maximise their language skills (e.g., speaking and math) by using their new and first language at same time.

\section{Recommendations}

This study suggests that English should be taught along with Turkish in early years education. The study understands that the language of instruction is Turkish in Turkey, but arrangements can be made by policymakers to enable teachers in order to teach children English flexibly. The study had limitations. One of the limitations was that it was conducted in one nursery. Another limitation was the number of participants that could be considered short.

\section{References}

Baker, C. (2007). Becoming bilingual through bilingual education. In P. Auer and L. Wei (eds) Handbook of Multilingualism and Multilingual Communication (pp.131-154). Berlin, Walter de Gruyter.

Baytas, M. O. \& Seyma, T. (2019). Translanguaging as a Pedagogical Approach with Syrian Refugee Learners in Turkey: Lessons Learned from a Collaborative Inquiry. AAAL Conference.

Bayyurt, Y. (2012). Eğitim sisteminde erken yaşta yabancı dil eğitimi [Foreign language education within 4+4+4 education system4+4+4]. 1. Yabancı Dil Eğitimi Çalıştayı [1. Foreign Language Teaching Workshop]. Hacettepe Üniversitesi, Ankara

Bayyurt, Y. (2013). Current perspectives on sociolinguistics and English language education. The Journal of Language Teaching and Learning, 1, 69-78.

Çetintaş, B.G. \& Yazici, Z. (2016). Teachers' opinions concerning bilingual education in early childhood: practice and experience in pre-school and nursery classes. Mediterranean Journal of Humanities, 173187.

Copland, F. \& Creese, A. (2015). Linguistic ethnography: collecting, analysing and presenting data. London: SAGE

Creese, A. \& Blackledge, A. (2015). Translanguaging and Identity in Educational Settings. Annual Review of Applied Linguistics, 35, 20-35.

García, O. (2009). Education, multilinguism and translanguaging in the 21 st century. In: T. Skutnabb-Kangas, R. Phillipson, A.K. Mohanty and M. Panda (eds.), Social Justice through Multilingual Education (pp.140-158). Bristol: Multilingual Matters.

García, O. \& Li Wei. (2014). Translanguaging: Language, bilingualism and education. New York: Palgrave Macmillan.

Gelir, İ. (2020). The investigation of co-teaching model in second language teaching in early years education. ELT Research Journal, 9(2), 135-145.

Gibbs, G.R. (2007). Analysing qualitative data. London: SAGE Publications.

Gort, M. \& Sembiante, S. F. (2015) Navigating hybridized language learning spaces through translanguaging pedagogy: Dual language preschool teachers' languaging practices in support of emergent bilingual children's performance of academic discourse. International Multilingual Research Journal, 9(1), 7-25.

Gregory, E. (2001) Sisters and brothers as language and literacy teachers: synergy between siblings playing and working together. Journal of Early Childhood Literacy, 1(3), 301-322.

Gregory, E. (2008) Learning to read in a new language: Making sense of words and worlds. London: Sage.

Kenner, C. (2004). Community school pupils reinterpret their knowledge of Chinese and Arabic for primary school peers. In E. Gregory, S. Long and D. Volk (Eds.) Many pathways to literacy: Young children learning with siblings, grandparents, peers and communities. (pp.105-116). London: Routledge.

Lantolf, J. P. \& Thorne, S.L. (2006). Sociocultural theory and the genesis of second language development. Oxford: Oxford University Press.

Lantolf, J., Thorne, S. L., \& Poehner, M. (2015). Sociocultural Theory and Second Language Development. In B. van Patten \& J. Williams (Eds.), Theories in Second Language Acquisition (pp. 207-226). New York: Routledge.

Lugossy, R. (2018). Whose challenge is it? Learners and teachers of English in Hungarian preschool contexts. In M. Schwartz (ed), Preschool bilingual education: Agency in interactions between children, teachers, and parents (pp.99-131). Switzerland: Springer

Mary, L. \& Young, A. S. (2017). From Silencing to Translanguaging: Turning the tide to support emergent bilinguals in transition from home to pre-school. In B. Paulsrud, J. Rosén, B. Straszer and Å. Wedin (eds), New perspectives on translanguaging and education (pp.108-128). Bristol, UK: Multilingual Matters.

Mifsud, C. L. \& Ann Vella, L. (2018). To mix languages or not? Preschool bilingual education in Malta. In M. Schwartz (ed), Preschool bilingual education: Agency in interactions between children, teachers, and parents (pp.57-98). Switzerland: Springer

Mitchell, R., Myles, F. \& Marsden, E. (2013). Second Language Learning Theories ( ${ }^{\text {rd }}$ ed) London: Routledge. 
Official Gazette (Ministry of Education). (2014). Regulations on preschool education and primary education institutions Retrieved December 05, 2020 from http://dspace.ceid.org.tr/xmlui/bitstream/handle/1/299/ekutuphane3.2.3.6.pdf?sequence=1\&isAllowed= $\mathrm{y}$

Prošić- Santovac, D. \& Radovič, D. (2018). Separating the languages in a bilingual preschool: To do or not to do? In M. Schwartz (ed), Preschool bilingual education: Agency in interactions between children, teachers, and parents (pp.27-56). Switzerland: Springer

Sarıca, E. (2019). Erken çocukluk döneminde ikinci dil eğitimi [Learning English as a second language in early years education]. [Unpublished Master's thesis]. Pamukkale Üniversitesi, Denizli.

Schwartz, M. \& Palviainen, Å. (2016). Twenty-first-century preschool bilingual education: facing advantages and challenges in cross-cultural contexts. International Journal of Bilingual Education and Bilingualism, 19(6), 603-613.

Schwartz, M., \& Asli, A. (2014). Bilingual teachers' language strategies: The case of an Arabic- Hebrew kindergarten in Israel. Teaching and Teacher Education, 38, 22-32.

Schwarz, M. and Gorbatt, N. (2018). "Fortunately, I found a home here that allows me personal expression": Co-teaching in the bilingual Hebrew-Arabic-speaking preschool in Israel. Teaching and Teacher Education, 71, 46-56.

Tarone, E. (2007). Sociolinguistic approaches to second language acquisition research 1997-2007. The Modern Language Journal, 91 (1), 837-848.

Ting, S.H. \& Jintang, L. (2020). Teachers and students' translanguaging practices in a Malaysian preschool. International Journal of Early Years Education, https://doi.org/10.1080/09669760.2020.1850429

Vygotsky, L. S. (1986). Thought and language (revised and edited by Alex Kozulin). Cambridge: MIT Press.

Vygotsky, L.S. (1978) Mind in Society: The Development of Higher Psychological Processes. Cambridge, MA, Harvard University Press.

Wood, D., Bruner, J., and Ross, G. (1976). The role of tutoring in problem solving. Journal of Child Psychology and Child Psychiatry, 17, 89-100.

Yuvayapan, F. (2019). Translanguaging in EFL classrooms: teachers' perceptions and practices. Journal of Language and Linguistic Studies, 15 (2), 678-694. 